\title{
P2Y nucleotide receptor silencing and its effect on glioma C6 calcium signaling
}

\author{
Dorota Wypych and Pawel Pomorski ${ }^{\varpi}$ \\ Laboratory of Molecular Basis of Cell Motility, Department of Biochemistry, Nencki Institute of Experimental Biology, Warsaw, Poland
}

\begin{abstract}
In our earlier studies of the signaling cross-talk between nucleotide receptors in an in vitro glioma model (C6 cell line) under prolonged serum deprivation conditions, a growth arrest of the cells and expression shift from $\mathrm{P}_{2} \mathrm{Y}_{1}$ to $\mathrm{P} 2 \mathrm{Y}_{12}$ receptors was found. The aim of the present work was to test if siRNA silencing of $\mathrm{P}_{2} \mathrm{Y}_{1}$ receptor changes $\mathrm{P}_{2} \mathrm{Y}_{12}$ expression similarly as following the serum deprivation and which physiological downstream pathways it affects. Here we demonstrate for the first time the efficiency of siRNA technology in silencing P2Y nucleotide receptors in glioma C6 cell line. Moreover, $\mathrm{P}_{2} \mathrm{Y}_{12}$ proved to be insensitive to the $\mathrm{P} 2 \mathrm{Y}_{1}$ receptor silencing. The effect of the $\mathrm{P}_{2} \mathrm{Y}_{1}$ silencing on calcium signaling was less pronounced then the extent of the protein change itself, exactly as was the case for the serum starvation experiments. Phosphorylation of ERK and Akt kinases were studied as the downstream effect of $\mathrm{P}_{2} \mathrm{Y}_{1}$ evoked signaling and similar effects as in the case of serum deprivation were found for ERK, and even stronger ones for Akt phosphorylation.
\end{abstract}

Key words: siRNA, P2Y receptors, nucleotide receptors, calcium signaling

Received: 21 November, 2012; revised: 04 December, 2012; accepted: 17 December, 2012; available on-line: 20 december, 2012

\section{INTRODUCTION}

Signaling between the cell environment and the cytoplasm is fundamental for the ability of life to adapt to the changing conditions as well as for of the regulation of the behavior of individual cells by the organism. In the cytoplasm, the signal is transmitted by so called secondary messengers, among which calcium ions are one of the most ubiquitous and versatile ones (Rasmussen et al., 1976).

An important class of cell surface receptors capable of evoking calcium signals in the cytoplasm is a heterogenic group of receptors known as nucleotide receptors (Burnstock, 1976; Abbracchio \& Burnstock, 1998; Braganhol et al., 2009). These plasma membrane proteins are activated by extracellular nucleotides: ATP, UTP and their derivatives (ADP, UDP, UDP-glucose, UDP-galactose) (Burnstock, 2007). The nucleotide receptors are of two main types: P2X and P2Y. P2X receptors $\left(\mathrm{P} 2 \mathrm{X}_{1-7}\right)$ belong to ligand-gated cation channels that after activation by ATP are able to form calcium transients (North, 2002). Glioma C6 cells (see below) in vitro express P2RX2, P2RX4, P2RX5 (Braganhol, et al., 2009) whereas P2RX7 expression is a matter of debate (De Vuyst et al., 2006; Wei et al., 2008; Braganhol, et al., 2009). Recently one of us proved that even though the $\mathrm{P} 2 \mathrm{X}_{7}$ protein is present in these cells, the receptor is inactive (Suplat-Wypych et al., 2010). Seven metabotropic G protein-coupled P2Y receptors are known so far: P2Y $\mathrm{Y}_{1,2,4,6,11,12,14}$ (Harden et al., 2010). All of them respond to several agonists: purines $\left(\mathrm{P}_{1,2,11,12}\right)$ as well as pyrimidines $\left(\mathrm{P}_{2,4,6,14}\right)$ and sometimes several P2Y receptors share the same ligand. Such example of the common ligand is ADP or its non-hydrolysable analog 2-methylthio-adenosine-5'-diphosphate (2MeSADP), which activate both $\mathrm{P}_{2} \mathrm{Y}_{1}$ and $\mathrm{P} 2 \mathrm{Y}_{12}$ receptors. However, the result of stimulation of these receptors is different as $P 2 Y_{1}$ is coupled to $G$ protein containing $G_{\alpha}$ subunit $G_{4}$ and $P 2 Y_{12}-G_{i}$. Thus, in response to $\mathrm{ADP}$ or $2 \mathrm{MeSADP}$ action either calcium signaling or inhibition of adenylate cyclase occurs, respectively.

The rat glioma C6 cell line was used in this work as an in vitro model of primary glial tumor cells. The cell line belongs to a non-excitable cell group (Baranska et al., 1995) and is derived from chemically-induced rat brain tumor (Benda et al., 1968). Glioma C6 shares several properties of astrocytic as well as oligodendrocytic progenitors and is often used as a biochemical model for studies related to astrocytes (Brismar, 1995). When injected into rodent brain these cells become morphologically similar to glioblastoma multiforme (Auer et al., 1981) and therefore they are used in both in vivo and in vitro studies of this kind of tumor (Jacobs et al., 2011). The expression and activity of several $\mathrm{P} 2 \mathrm{Y}$ receptors: $\mathrm{P} 2 \mathrm{Y}_{1}$, $\mathrm{P}_{2} \mathrm{Y}_{2}, \mathrm{P} 2 \mathrm{Y}_{4}, \mathrm{P}_{2} \mathrm{Y}_{6}, \mathrm{P} 2 \mathrm{Y}_{12}, \mathrm{P}_{13} \mathrm{Y}_{13}$ and $\mathrm{P} 2 \mathrm{Y}_{14}$ in glioma C6 has been well-documented in the literature (for review see: Wypych \& Baranska, 2013).

In the past, several studies performed in Jolanta Baranska's laboratory, in which the authors of the present paper also participated, showed interesting crosstalk between $G_{\mathrm{q}}$ - and $G_{i}$-dependent pathways in the physiology of glioma C6 cells. This phenomenon was revealed by long-term serum starvation which affected the level of both $\mathrm{P}_{2} \mathrm{Y}_{1}$ and $\mathrm{P}_{2} \mathrm{Y}_{12}$ receptors protein. While the $\mathrm{P}_{2} \mathrm{Y}_{1}$ protein level as well as the calcium signal evoked by its activation decreased during serum starvation, the level of $\mathrm{P}_{2} \mathrm{Y}_{12}$ receptor rose (Krzeminski et al., 2007). Those changes were interpreted as a shift from proliferative to pro-survival behavior under the unfavorable conditions of long-time serum deprivation.

The calcium signal evoked by $G_{\mathrm{q}}$-coupled receptors, including P2Y nucleotide receptors, consists of two components and is preceded by activation of phospho-

e-mail: p.pomorski@nencki.gov.pl

Abbreviations: 2MeSADP, 2-methylthio-adenosine-5'-diphosphate (IUPAC name: [(2R,3S,4R,5R)-5-(6-amino-2-methylsulfanylpurin9-yl)-3,4-dihydroxyoxolan-2-yl]methyl phosphono hydrogen phosphate); CCE, calcium capacitative entry; TIRF, total internal reflection microscopy. 
lipase $C \beta$ and production of $\mathrm{IP}_{3}$ followed by $\mathrm{IP}_{3}$ action on its receptor $\left(\mathrm{IP}_{3} \mathrm{R}\right)$ on the endoplasmic reticulum (ER). This in turn leads to calcium release from ER cisternae (intracellular calcium stores) via $\mathrm{IP}_{3} \mathrm{R}$. In SOCE (Store Operated Calcium Entry) the emptying of the ER cisternae is followed by opening of a special class of channels in the plasma membrane, so called store operated calcium channels (SOCs), and calcium flows from the cell environment into the cytoplasm. This influx is also known as capacitative calcium entry. Thus, there are two sources of calcium signal: intracellular calcium stores and the extracellular space.

A study of calcium signaling of serum-deprived glioma C6 cells revealed that the strength of the P2Y 1 receptor evoked calcium signal did not always correlate with the receptor protein level, but the observed phenomenon was explained by a compensating activity of $\mathrm{P}_{2} \mathrm{Y}_{12}$ receptor (Suplat et al., 2007).

Up to now there are no literature data about the regulation of transcription of P2RY1 and P2RY12 genes. To test the hypothesis that a decreased $\mathrm{P}_{2} \mathrm{Y}_{1}$ expression enhances the expression of $\mathrm{P}_{2} \mathrm{Y}_{12}$ receptor, we decided to silence the $\mathrm{P} 2 \mathrm{Y}_{1}$ receptor by siRNA and to test the effect of that on $\mathrm{P} 2 \mathrm{Y}_{12}$ protein level and the ability of the cells for nucleotide-dependent calcium signaling. The RNAi technology has proven to be an efficient tool to suppress the expression of targeted genes and, although never used earlier to target $\mathrm{P} 2 \mathrm{Y}$ nucleotide receptors in glioma cells, it proved to be quite efficient in knockingdown $\mathrm{P} 2 \mathrm{X}_{7}$ receptor (Deli et al., 2007).

\section{MATERIALS AND METHODS}

Cell culture. Rat glioma C6 cells were obtained from the American Type Culture Collection and cultured in DMEM (Invitrogen Life Technologies, USA) supplemented with $10 \%(\mathrm{v} / \mathrm{v})$ newborn calf serum (NCS) (Invitrogen), penicillin $(50 \mathrm{IU} / \mathrm{ml})$ and streptomycin $(50 \mu \mathrm{g} /$ $\mathrm{ml}$ ) (Sigma-Aldrich, Germany) in a humidified atmosphere of $5 \% \mathrm{CO}_{2}$ at $37^{\circ} \mathrm{C}$. For serum-starvation experiments, the medium was changed to DMEM without serum for up to $96 \mathrm{~h}$ (Czajkowski et al., 2004; Krzeminski, et al., 2007; Suplat, et al., 2007).

$\mathbf{P} 2 Y_{1}$ receptors silencing with siRNA. In all experiments a set of four dsRNAs selected for four regions of rat P2RY1 mRNA (RefSeq NM_012800) was used (Dharmacon, Thermo Scientific, USA). Their sequences are shown in Table 1. Concentrations of siRNA were determined at $260 \mathrm{~nm}$.

Glioma C6 transfection. Automatic electroporation system Amaxa (Lonza, USA) was used for cell transfection and only passages under 30 were used. Briefly, after non-enzimatic detachement (Cell Dissociation Solution, Sigma-Aldrich, Germay) $1.5 \times 10^{6}$ cells were used for one reaction. After centrifugation $(200 \times g$ for 10 minutes) the cells were resuspended in $100 \mu$ l of electroporation buffer (Cell Line Nucleofector Solution V, Lonza, USA). Cells were electroporated using a survival-promoting

Table 1. dsRNA sequences used for silencing $P 2 Y_{1}$ receptor.

\begin{tabular}{lll}
\hline & Sense & Antisense \\
\hline 1 & UGGCACUGGGAUUCGGAAAUU & 5'-P UUUCCGAAUCCCAGUGCCAUU \\
\hline 2 & GAUGAGUACCUGCGAAGUUUU & 5'-P AACUUCGCAGGUACUCAUCUU \\
\hline 3 & GGAUUAAUUGUUAGAGCUUUU & 5'-P AAGCUCUAACAAUUAAUCCUU \\
\hline 4 & CGGUGUACAUGUUCAAUUUUU & 5'-P AAAUUGAACAUGUACACCGUU \\
\hline
\end{tabular}

program in a Nucleofector II electroporator (Lonza, USA). For each electroporation from 0.25 to $3 \mu \mathrm{g}$ of siRNA was used. Immediately after electroporation cells were conditioned in $500 \mu \mathrm{l}$ of fresh culture media and then cultured appropriately for further experiments. As a positive control of electroporation, $2.5 \mu \mathrm{g}$ of GFPcoding plasmid was used (pmaxGFPTM, Lonza, USA). As negative controls, cells were either incubated in the presence of $3 \mu \mathrm{g}$ siRNA without electroporation or electroporated in electroporation buffer with no siRNA. The next day, transfection efficiency was calculated as a ratio between the number of GFP-expressing cells and all visible cells observed in at least 5 fields. A Nikon Diaphot microscope equipped with a $10 \times 0.5 \mathrm{NA}$ dry LWD lens was used using overlay of fluorescence and DIC Nomarski and the images were registered with a Retiga 1300 cooled digital camera (QImaging, Canada) controlled by the $\mu$ Manager program (Edelstein et al., 2010).

Immunodetection of proteins. three days after electroporation cells were lysed in $100 \mu$ of RIPA buffer containing $150 \mathrm{mM} \mathrm{NaCl}, 1.0 \%$ IGEPAL ${ }^{\circledR}$ CA-630, $0.5 \%$ sodium deoxycholate, $0.1 \%$ SDS, $50 \mathrm{mM}$ Tris, $\mathrm{pH}$ 8.0 (Sigma-Aldrich, Germany) with a cocktail of protease and phosphatase inhibitors, (Roche, Germany), and centrifuged for $10 \mathrm{~min}$ at $10000 \times g$ at $4^{\circ} \mathrm{C}$. After determination of protein concentration with Bradford reagent (Bio$\mathrm{Rad}), 20 \mu \mathrm{g}$ of protein was suspended in Leammlie buffer $(50 \mathrm{mM}$ Tris $/ \mathrm{HCl}$ at $\mathrm{pH} 6.8,2 \%$ SDS, $0.1 \%$ bromophenol blue, $10 \%$ glycerol and $5 \% \beta$-mercaptoethanol) and denatured at $98^{\circ} \mathrm{C}$ for $5 \mathrm{~min}$. For gel electrophoresis $10 \%$ polyacrylamide gel was used. Proteins were then transferred to a nitrocellulose filter $(0.45 \mu \mathrm{m}$, Bio-Rad, Germany) by wet transfer in a buffer containing $25 \mathrm{mM}$ Tris/HCl, $192 \mathrm{mM}$ glycine, 0.1\% SDS, 10\% methanol for $60 \mathrm{~min}$ at $400 \mathrm{~mA}$ in a cold room. Transfer efficiency was controlled by staining in Ponceau S solution (Sigma Aldrich, Germany).

Nitrocellulose membranes were incubated at room temperature for 60 minutes in blocking buffer composed of $5 \% \mathrm{w} / \mathrm{v}$ nonfat dry milk in PBS with $0.05 \%$ Tween 20 (PBS-T) and then incubated at $4^{\circ} \mathrm{C}$ overnight in blocking buffer containing primary antibodies. The following dilutions of primary antibodies were used: 1:1000 anti-P2Y $Y_{1}$ rabbit, 1:200 anti-P2Y 12 rabbit (both from Alomone Labs, Israel), 1:1000 both anti-phospho p-42/44 MAPK (Erk1/2) and anti-phospho-Akt (Cell Signaling, USA); for housekeeping control, 1:50000 monoclonal anti- $\beta$-actin conjugated with horseradish peroxidase (Sigma-Aldrich, Germany) was used. After four 10-minute washes in PBS-T, the blots were incubated for $1 \mathrm{~h}$ with anti-rabbit secondary antibody (1:5000) conjugated with horseradish peroxidase (Pierce, USA). West Femto Maximum Sensitivity Substrate (Pierce, USA) was used to detect horseradish peroxidase activity and evaluate the amount of protein.

To evaluate changes in the amounts of $\mathrm{P}_{2} \mathrm{Y}_{1}$ and $\mathrm{P}_{2} \mathrm{Y}_{12}$ receptors, membranes were first detected for $\mathrm{P} 2 \mathrm{Y}_{1}$ followed by $\beta$-actin and then for $\mathrm{P}_{2} \mathrm{Y}_{12}$ with stripping between different antibodies. The same procedure was used for phospho-Erk and phospho-Akt. Stripping buffer contained $0.2 \mathrm{M}$ glycine, $0.1 \%$ SDS and $0.01 \%$ Tween 20. After two rounds of stripping ( 7 minutes each), membranes were washed twice for 10 minutes in PBS and twice for 5 minutes in PBS-T, followed by blocking and hybridization as above. The specificity of the anti-P2Y $Y_{1}$ and anti-P2 $Y_{12}$ antibodies was confirmed as in (Krzeminski, et al., 
2007) by incubation of the primary antibodies with antigen peptide provided by the manufacturer. A 1:1 antigen to antibody mixture was pre-incubated for $1 \mathrm{~h}$ (with agitation) in blocking buffer and then membrane was processed as for primary antibody.

Multiple bands visible on all $\mathrm{P}_{2} \mathrm{Y}_{1}$ blots are common problem for most P2Y receptor detection experiment. As discussed earlier, it is not nonspecific staining but the result of several glycosylation forms of the same receptor present in the cell. Declycosylation of cell extract by $\mathrm{N}$-glycosidase $\mathrm{F}$ results in one band on the western blot (Krzeminski et al., 2008).

Analysis of the immunodetected proteins. Western blots were imaged on X-Ray film (Kodak), scanned and then densitometry was performed with ImageJ program plugin (Schneider et al., 2012). Signal intensity was normalized first to $\beta$-actin than to that in control conditions and the values shown are mean of at least three experiments $\pm S D$. In order to determine statistical significance of differences nonparametric Mann-Whitney U test was used. The significance is labeled $(*)$ for $p<0.05$, (***) for $p<0.001$ and a lack of statistical significance is presented as (-).

Immunostaining of $\mathrm{P}_{2} \mathrm{Y}_{1}$ receptors for wide field and TIRF microscopy. Cells were grown on TIRFcompatible, high precision $\mathrm{N}^{\mathrm{o}} 1.5$ coverslips (Paul Marienfeld $\mathrm{GmbH \& Co.KG}$, Germany). After washing twice with PBS, cells were fixed in cold $\left(4^{\circ} \mathrm{C}\right)$ acetone for 3 min, rehydrated in PBS for at least 10 minutes at RT and then permabilized for 10 minutes with $0.1 \%$ Triton X100 (Romil Chemicals, UK). To confirm specificity of the staining, primary anti-P2 $\mathrm{Y}_{1}$ antibody was preincubated with the peptide provided by the manufacturer at a 1:1 dilution, in the same way as in the case of western blot. After careful washing, slides were incubated in $2.5 \%$ NCS in BPS (ICC blocking solution) for 1 hour to block unspecific binding and then stained overnight $\left(4^{\circ} \mathrm{C}\right)$ with primary anti-P2Y $\mathrm{Y}_{1}$ antibody (Alomone, Israel) diluted 1:200 in ICC blocking solution. After three 10-minute washes in PBS slides were incubated with secondary goat anti-rabbit IgG antibodies conjugated with Alexa488 (Invitrogen, Life Technologies, USA) in ICC blocking solution (1:600) for 2 hours at RT. After three 10-minute final washes in PBS, specimens were mounted with VectaShield mounting medium (Vector Laboratories, UK). For evaluation of $\mathrm{P}_{2} \mathrm{Y}_{1}$ receptor staining a Carl Zeiss Laser TIRF3 system was used. It contained a Carl Zeiss Axio Observer Z.1 microscope stand (Carl Zeiss, Germany) equipped with a $488 \mathrm{~nm} / 100 \mathrm{~mW}$ argon laser for TIRF and a mercury arc lamp for wide field fluorescence microscopy. High numerical aperture planapochromat lens $100 \times 1.46 \mathrm{NA}$ was used to provide total reflection of side introduced laser beam in the coverslip and allow the TIRF mode. Images were collected with a high efficiency back-thinned CCD camera Quantem 512SC (Photometrics, Germany) for $n$ cells from at least 5 different areas. The microscope was controlled by AxioVision 4.7.2.0 software (Carl Zeiss, Germany). Ratio between images of background-corrected TIRF and wide field fluorescence images was calculated with MetaMorph 7.5.6.0 software (Danaher Corporation, USA). In graphs, the ratio TIRF/WF in control conditions is presented as 1 and relative changes (mean \pm S.E.) of the parameter are shown. The imaging in each experimental condition was performed at least three times.

Calcium imaging. The experiments were performed as described before (Suplat-Wypych, et al., 2010). Briefly, before experiments cells on coverslips were washed once with PBS and once with solution containing $137 \mathrm{mM}$
$\mathrm{NaCl}, 2.7 \mathrm{mM} \mathrm{KCl}, 1 \mathrm{mM} \mathrm{Na} \mathrm{HPO}_{4}, 25 \mathrm{mM}$ glucose,

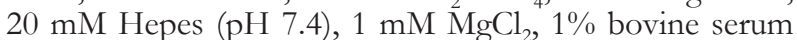
albumin and $2 \mathrm{mM} \mathrm{CaCl}_{2}$ (standard buffer). The cells were then incubated at $37^{\circ} \mathrm{C}$ for $30 \mathrm{~min}$ in the standard buffer with $1 \mu \mathrm{M}$ Fura-2 AM. Thereafter, the coverslips were mounted in a chamber on a Nikon Diaphot inverted-stage microscope equipped with a fluo $\times 40 / 1.3 \mathrm{NA}$ oil-immersion objective lens. Fura-2 digital fluorescence microscopy was used to determine changes in the intracellular calcium levels $\left[\mathrm{Ca}^{2+}\right]_{\mathrm{i}}$ (Grynkiewicz et al., 1985).

Ludl Lep MAC 5000 filter wheel system with a Chroma Fura-2 filter set was used for illumination of specimens. Images were acquired using an Andor Luca $\mathrm{R}$ digital EMCCD camera (Andor, Irland). Data processing was carried out using iQ Live Cell Imaging Software (Andor, Irland) and Matlab ${ }^{\circledR}$ software (The Mathworks Inc, USA). All data are expressed as 340/380 nm-induced fluorescence of Fura-2 ratio changes against time $(\Delta 340 / 380)$. Each experiment was repeated at least three times. MeSADP (Sigma-Aldrich, Germany) at $10 \mu \mathrm{M}$ was used to evoke P2 $\mathrm{Y}_{1}$-dependent calcium signal. Calcium responses against time are expressed as means of $(n)$ cells. Changes in the calcium response were calculated as the relative changes of integrals from 100 consecutive measuring points after adding the agonist (mean \pm S.D.).

\section{RESULTS}

\section{The receptor protein level during serum deprivation}

Previously published serum starvation experiments (Krzeminski et al., 2007) were carried out in significantly different conditions. Change of the glioma C6 cell line passage from above 40 to below 30 was forced by electroporation protocol and lead to difference in obtained results large enough to repeat receptor level measurements as a reference for further research.

Using western blot analysis, we measured relative protein content of $\mathrm{P} 2 \mathrm{Y}_{1}$ and $\mathrm{P} 2 \mathrm{Y}_{12}$ receptors in glioma C6 cells during prolonged, $96 \mathrm{~h}$ serum deprivation as a starting point of the study (Fig. 1). The amount of P2Y receptor protein fell to less than one third of control level $(10-30 \%$, depending on the experiment). At the same time the amount of $\mathrm{P}_{2} \mathrm{Y}_{12}$ receptor protein rose to about $150 \%$ of the control. Although those changes were less pronounced than the ones reported previously (Krzeminski, et al., 2007), the trends were exactly the same: the level of $\mathrm{P}_{2} \mathrm{Y}_{1}$ receptor was falling, and of the $\mathrm{P}_{2} \mathrm{Y}_{12}$ receptor rising and, crucially, in both series of measurements, the increase of $\mathrm{P}_{2} \mathrm{Y}_{12}$ receptor level during prolonged serum starvation was three times smaller than decrease of $\mathrm{P} 2 \mathrm{Y}_{1}$ receptor level. In other words, the rise of $\mathrm{P}_{2} \mathrm{Y}_{12}$ is evident, but less intense than the fall of $\mathrm{P}_{2} \mathrm{Y}_{1}$ receptor. Experiments were performed four times, data pooled and processed together.

\section{Silencing of $\mathrm{P}_{2} \mathrm{Y}_{1}$ receptors by siRNA}

Since we wanted to evaluate the effect of progressive $\mathrm{P} 2 \mathrm{Y}_{1}$ silencing, and not just a lack of $\mathrm{P} 2 \mathrm{Y}_{1}$ protein, the transient siRNA approach was chosen. The poor efficiency of other transfection methods (around 3\% after lipofectamine treatment, not shown) made us use electroporation with the Amaxa system as an effective way to deliver small RNA molecules into cells. Preliminary experiment with GFP vector (pmaxGFPTM, Lonza, USA) proved transfection efficiency above 40-70\%. The best result of silencing we observed $48 \mathrm{~h}$ after electropo- 


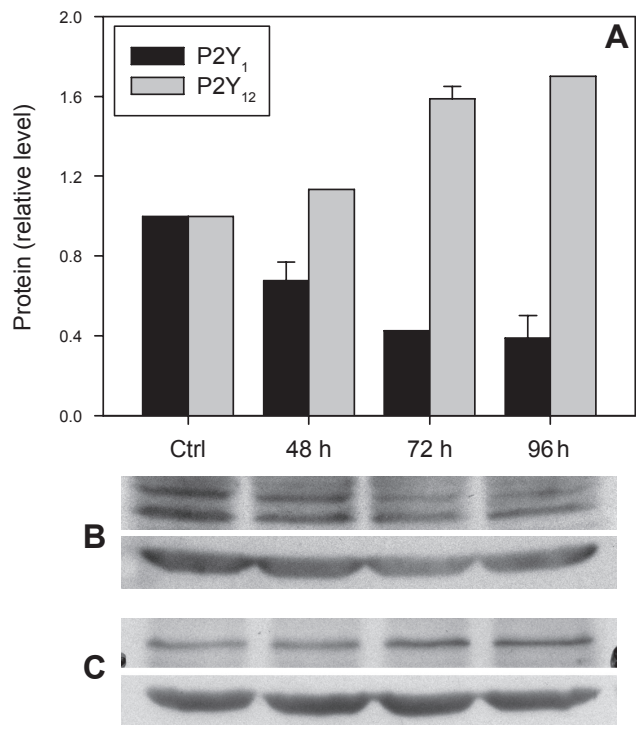

Figure 1. Effect of long-term starvation on $\mathrm{P}_{2} \mathrm{Y}_{1}$ and $\mathrm{P} 2 \mathrm{Y}_{12}$ receptors protein level

(A) Densitometric analysis of western blot. Four independent experiments were performed. (B) Typical result of $\mathrm{P} 2 \mathrm{Y}$, receptor protein detection, here shown control, $48 \mathrm{~h}, 72 \mathrm{~h}$ and $96 \mathrm{~h}$ of serum-deprivation time points. Lower row: $\beta$-actin as housekeeping protein reference. (C) Typical example of $\mathrm{P} 2 \mathrm{Y}_{12}$ receptor protein detection, here shown control, $48 \mathrm{~h}, 72 \mathrm{~h}$ and $96 \mathrm{~h}$ time points of serum deprivation. Lower row: $\beta$-actin as housekeeping protein reference.

ration with siRNA. Figure 2 shows dose dependency of $\mathrm{P} 2 \mathrm{Y}_{1}$ receptor silencing on the amount of siRNA loaded into the cells. The siRNA dose of $0.25 \mu \mathrm{g}$ was ineffective $(1.02 \pm 0.15)$, and the effect was growing with the dose of siRNA $(0.72 \pm 0.47$ for $0.5 \mu \mathrm{g})$ up to $0.32 \pm 0.07$ for

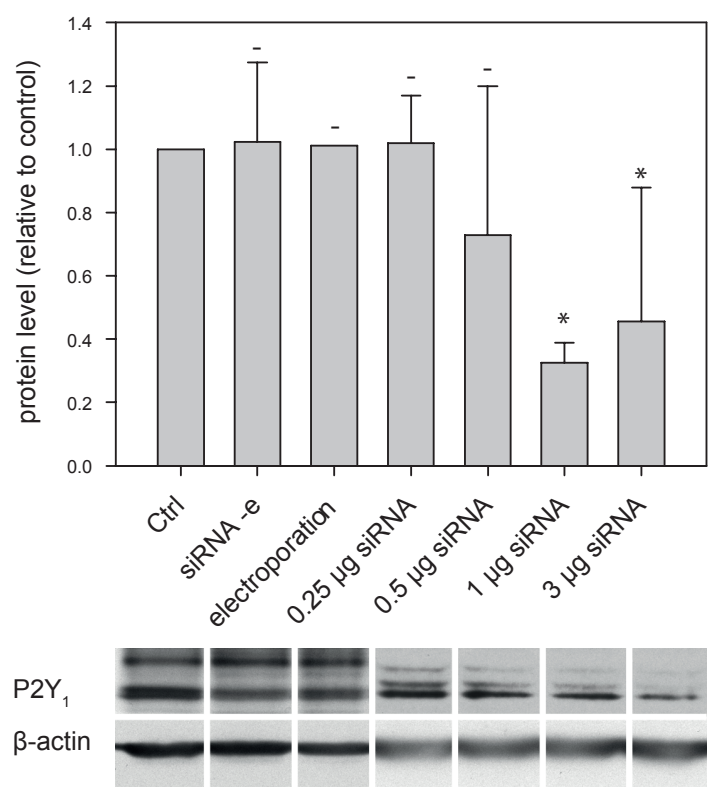

Figure 2. Silencing of $\mathrm{P}_{2} \mathrm{Y}_{1}$ receptor by siRNA

P2Y protein level two days after electroporation of glioma C6 cells with specific siRNA. Densitometric analysis of the western blot, from left: control, cells incubated with specific siRNA without electroporation, cells electroporated in the control medium, without siRNA, growing dose of siRNA: $0,25 \mu \mathrm{g}, 0,5 \mu \mathrm{g}, 1 \mu \mathrm{g}$ and $3 \mu \mathrm{g}$. The dose-dependent activity of specific siRNA can be observed from $0,25 \mu \mathrm{g}$ to $1 \mu \mathrm{g}$ dose. Presented blots come from two representative experiments, $\beta$-actin as housekeeping protein reference.
$1 \mu \mathrm{g}$. With $3 \mu \mathrm{g}$ we observed erratic results $(0.45 \pm 0.42)$, showing that the effect may not be specific any longer. It could be due to a too high (higher than recommended by the producer) dilution of the sample by siRNA. The addition of $3 \mu \mathrm{g}$ of siRNA without electroporation or the electroporation without the siRNA in the medium did not result in any statistically significant changes of $\mathrm{P} 2 \mathrm{Y}_{1}$ receptor protein level in the cells $(1.02 \pm 0.25$ and 1.01, respectively). Altogether it shows that the observed results are specific consequences of the siRNA activity in glioma C6 cells, and are not the result of the experimental procedure itself. For further experiments we decided to use $1 \mu \mathrm{g}$ of siRNA.

The maximal level of silencing was observed after $48 \mathrm{~h}$ of silencing with $1 \mu \mathrm{g}$ siRNA $(0.32 \pm 0.07$ of control) what may be caused by the slow turnover of the receptor in the idle cells. To find out if the protein was still present on the plasma membrane, we decided to use TIRF (total internal reflection fluorescence) microscopy (Fig. 3). TIRF microscopy allows one to observe a 100-nm layer of the specimen close to the coverglass. With this method we evaluated the amount of the P2Y receptor protein present on the plasma membrane. In contrast, in wide field (WF) fluorescent microscopy the signal is proportional to the total amount of a protein in the cell. Thus, the of ratio of fluorescence intensity in the TIRF channel to that in the wide field channel is proportional to the ratio between membrane and total pool of receptors. We measured the TIRF/WF signal ratio of immunocytochemically stained $\mathrm{P} 2 \mathrm{Y}_{1}$ receptors and found that $48 \mathrm{~h}$ after siRNA administration the amount of $\mathrm{P}_{2} \mathrm{Y}_{1}$ receptors on the cell surface fell faster than did the total receptor protein level (calibrated ratio:
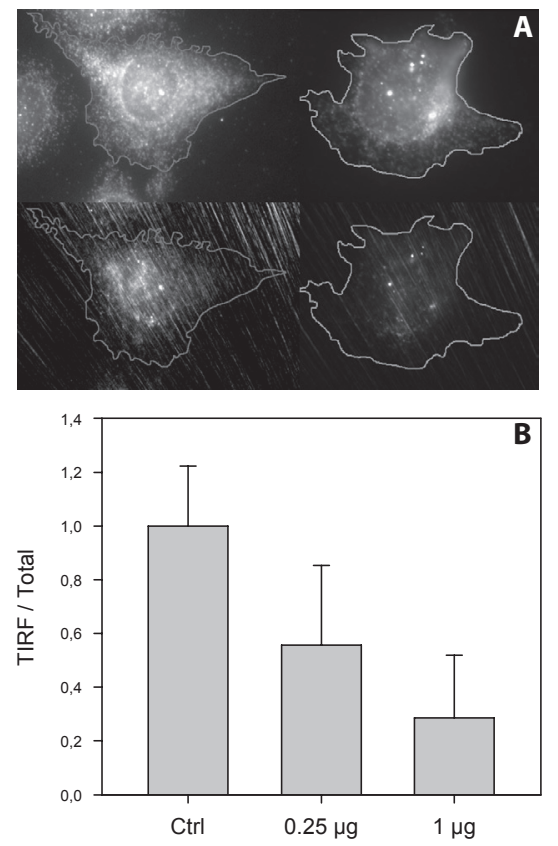

Figure 3. Distribution of $\mathrm{P}_{2} \mathrm{Y}_{1}$ receptor after prolonged siRNA silencing

Glioma C6 cells were stained with anti-P2Y, antibody and visualized both in wide field (WF) and total internal reflection fluorescence (TIRF) microscopy. (A) (upper row) Fluorescence image of control C6 cell stained with antibody against P2Y, receptor. The same cell pictured in the TIRF mode (lower row). Left column: control cells, right column: cells with $\mathrm{P} 2 \mathrm{Y}$, receptors silenced by 1 $\mu \mathrm{g}$ dose of siRNA. (B) Bars (mean \pm S.E.) present the ratio between TIRF and WF fluorescence intensity, proportional to the ratio between internalized and membrane fraction of receptor. 


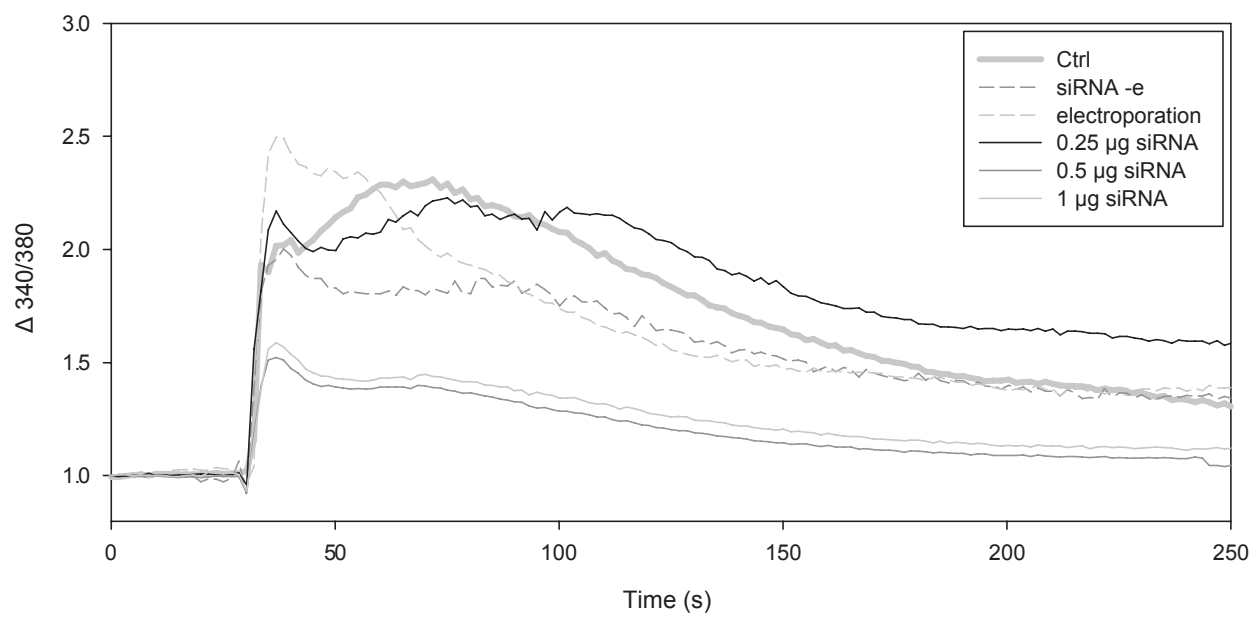

Figure 4. siRNA silencing of $\mathrm{P} 2 \mathrm{Y} 1$ receptor - effect on calcium signaling

Glioma C6 cells were loaded with Fura-2 AM and signal evoked by $10 \mu \mathrm{M} 2 \mathrm{MeSADP}$ in the presence of $2 \mathrm{mM} \mathrm{CaCl}_{2}$ was studied. Thick grey plot shows control cells without any treatment $(n=267)$. Dashed plots present calcium signal of the transfection control experiments: medium grey - cells incubated with $1 \mu \mathrm{g}$ siRNA but not electroporated $(n=282)$ and light grey - cells electroporated in absence of siRNA $(n=412)$. Note that calcium signal of the electroporated cells has stronger ER release phase and shorter capacitative phase. All plots present the mean response from $n$ number of cells as indicated in brackets. Solid plots present calcium signal of the cells with P2Y, protein knock-down by siRNA: black $-0.25 \mu \mathrm{g}(\mathrm{n}=213)$, medium grey $-0.5 \mu \mathrm{g}(\mathrm{n}=254)$, light grey $-1 \mu \mathrm{g}(\mathrm{n}=187)$. siRNA doses which earlier significantly lowered $\mathrm{P}_{2} \mathrm{Y}_{1}$ receptor protein level also strongly inhibited calcium signal.

control $1.0 \pm 0.01,0.5 \mu \mathrm{g}$ siRNA: $0.55 \pm 0.014$ and $1.0 \mu \mathrm{g}$ $0.29 \pm 0.011)$.

\section{Physiological effect of $\mathrm{P}_{2} \mathrm{Y}_{1}$ receptor silencing - calcium signaling}

Knowing the effects of individual siRNA doses on the total $\mathrm{P}_{2} \mathrm{Y}_{1}$ protein level and its level in the cell membrane, we could test the influence of both the experimental procedure and receptor knock-down on the direct signaling effect of its activation: the calcium signal in the cytoplasm. Evoked by $10 \mu \mathrm{M}$ MeSADP, it was studied with Fura-2 ratiometry, as described in Materials and Methods. Dashed lines in figure 4 present the transient plots in control experiments while solid ones in siRNA-treated cells. It worth mentioning, that electroporation of the cells without siRNA changes the shape of the calcium signal in comparison with control, even 48 hours after electroporation. The initial peak of the signal

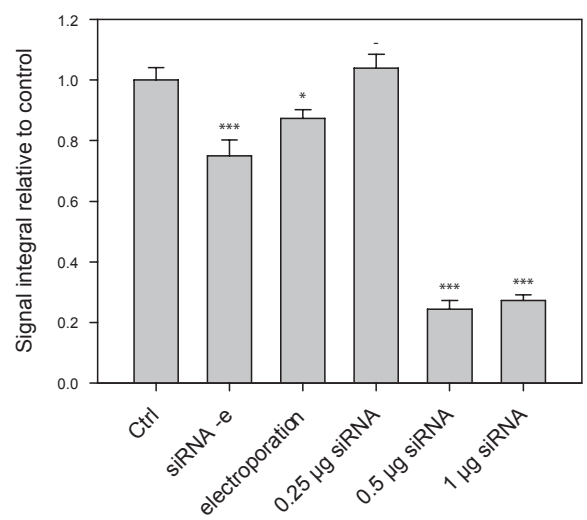

Figure 5. siRNA silencing of $P 2 Y_{1}$ receptor - quantification of calcium signaling

Signals presented in Fig. 4 were integrated. Both negative controls groups (cells incubated with $3 \mu \mathrm{g}$ siRNA without electroporation and electroporation in absence of siRNA) cause slight, but statistically significant inhibition of the calcium signal. Such an effect is not visible in cells electroporated with low $(0.25 \mu \mathrm{g})$ dose of siRNA. Higher doses $(0.5$ and $1 \mu \mathrm{g})$ reduced signal very strongly, however the effect is not dose dependent. (calcium release form ER) reached higher values and the second, CCE sustained phase, even if initially stronger, disappeared faster. A similar signal shape was seen in all siRNA-treated cells, with no CCE phase, suggesting some long-term influence of electroporation on cell membranes. To quantify the effect of $\mathrm{P}_{2} \mathrm{Y}_{1}$ siRNA administration on the calcium signal strength, we decided to calculate integrals of the transients, to compare plots with slightly different shapes (Fig. 5). Contrary to the protein level effects, both electroporation and incubation with siRNA without electroporation led to small but statistically significant diminishing of the signal $(0.75 \pm 0.05$ for cells incubated with siRNA and $0.87 \pm 0.03$ for cells electroporated in absence of siRNA, both as fraction of control signal). Surprisingly, we did not observe such an effect after electroporation with low dose $(0.25 \mu \mathrm{g})$ of siRNA (1.04 \pm 0.04$)$. The effect of the siRNA doses, which significantly changed the protein level was several times stronger. Surprisingly, we did not observe the dose-dependency as in the protein level $(0.24 \pm 0.03$ for $0.5 \mu \mathrm{g}$ of siRNA and $0.27 \pm 0.02$ for $1 \mu \mathrm{g}$ of siRNA).

\section{Physiological effect of $\mathrm{P}_{2} \mathrm{Y}_{1}$ receptor silencing - downstream effects}

We also studied the level of phosphorylation of ERK1/2 (p44/p42) and Akt, well known targets of the calcium signal in glioma C6 cells. Phosphorylation of both proteins was studied up to $120 \mathrm{~min}$ after induction of cells by $10 \mu \mathrm{M}$ 2MeSADP (Fig. 6). Control cells (black bars) were compared with those electroporated with $1 \mu \mathrm{g}$ of siRNA silencing the $\mathrm{P} 2 \mathrm{Y}_{1}$ receptor (grey bars). While Erk1/2 phosphorylation was only partially (more than two times) diminished, Akt phosphorylation was practically blocked.

\section{Effect of $\mathrm{P}_{2} \mathrm{Y}_{1}$ receptor knock-down by siRNA on $\mathrm{P}_{2} \mathrm{Y}_{12}$ receptor protein level}

The main goal of this work was to find out if the increase of the $\mathrm{P}_{2} \mathrm{Y}_{12}$ protein level observed during serum deprivation of C6 glioma cells was a simple compensatory effect of the $\mathrm{P}_{2} \mathrm{Y}_{1}$ receptor level fall. To evalu- 

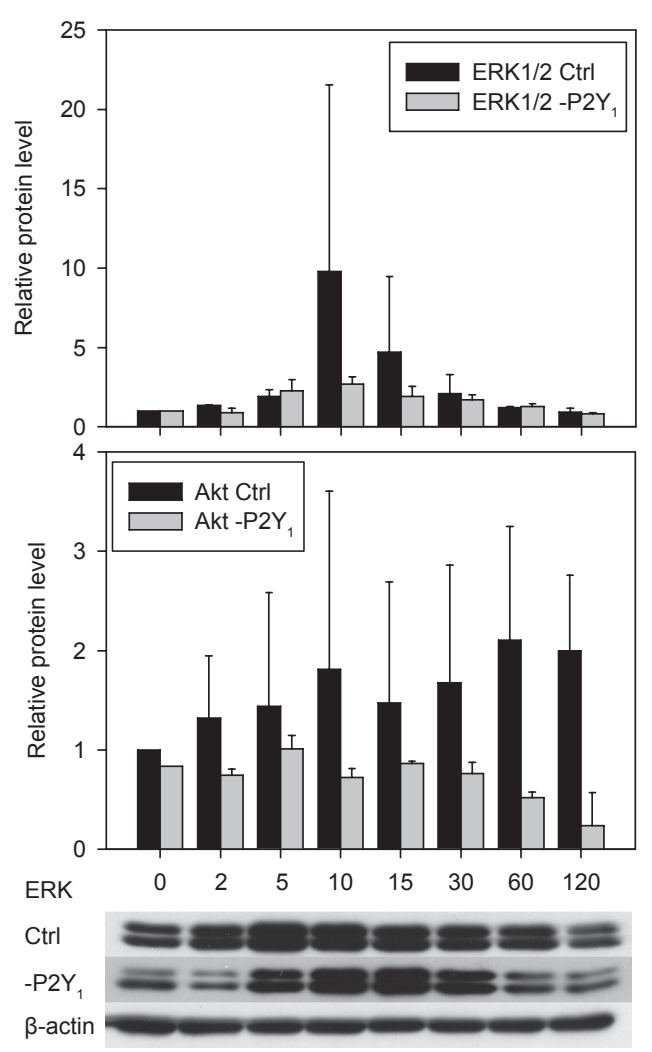

Akt

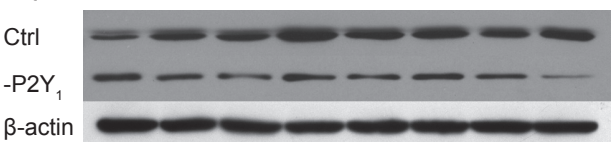

Figure 6. siRNA silencing of $\mathrm{P}_{2} \mathrm{Y}_{1}$ receptor - effect on downstream signal

Phosphorylation of Erk1/2 kinase (A) and Akt (B) was studied in control cells and cells electroporated with $1 \mu \mathrm{g}$ siRNA in several time points after $10 \mu \mathrm{M}$ 2MeSADP stimulation. After silencing of $\mathrm{P}_{2} \mathrm{Y}_{1}$ receptor (grey bars) the level of Erk1/2 phosphorylation is strongly attenuated in comparison with control cells (black). The Akt Phosphorylation is practically blocked by $\mathrm{P}_{2} \mathrm{Y}_{1}$ receptor knockdown by siRNA. Representative blots together with $\beta$-actin as housekeeping protein reference shown.

ate this we analyzed $\mathrm{P} 2 \mathrm{Y}_{12}$ protein level in parallel with $\mathrm{P}_{2} \mathrm{Y}_{1}$ during siRNA P2Y ${ }_{1}$ silencing (Fig. 7). The amount of $\mathrm{P}_{2} \mathrm{Y}_{12}$ reached $1.20 \pm 0.17$ for siRNA administration without electroporation, 1.16 for electroporation without siRNA, $1.03 \pm 0.07$ for $0.25 \mu \mathrm{g}$ siRNA, $0.92 \pm 0.07$ for $0.5 \mu \mathrm{g}$ siRNA, $1.02 \pm 0.02$ for $1.0 \mu \mathrm{g}$ siRNA, and $1.13 \pm 0.11$ for $3.0 \mu \mathrm{g}$ siRNA. There was no influence of the $\mathrm{P}_{2} \mathrm{Y}_{1}$ protein depletion on the $\mathrm{P} 2 \mathrm{Y}_{12}$ receptor level. The observed differences were small and statistically insignificant.

\section{DISSCUSION}

This study clearly shows that siRNA silencing of P2Y nucleotide receptors is a promising experimental approach. The siRNA knock-out achieved in the present work was efficient but not complete. It is better than that reported by Deli et al. (2007) for the $\mathrm{P} 2 \mathrm{X}_{7}$ receptor in melanoma cells (about 50\% of downregulation) and similar to the one recently reported by Crooke et al. (2009) and Martin-Gil et al. (2012) both on P2Y receptor. This level of efficiency is probably a result of two

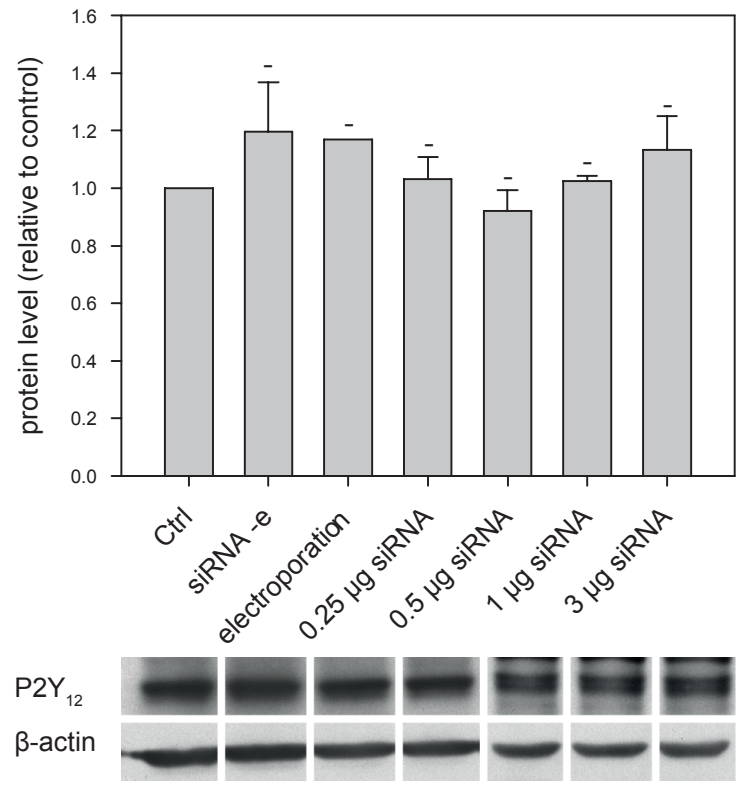

Figure 7. siRNA silencing of $\mathrm{P} 2 \mathrm{Y}_{1}$ receptor - effect on $\mathrm{P} 2 \mathrm{Y}_{12}$ receptor protein level

Glioma C6 cells content of $\mathrm{P}_{2} \mathrm{Y}_{12}$ protein level after electroporation with $1 \mu \mathrm{g}$ of specific siRNA. Densitometric analysis of western blot of three independent experiments. From left: control, cells incubated with $3 \mu \mathrm{g}$ of siRNA without electroporation, cells electroporated in the eletroporation buffer, without siRNA, growing dose of siRNA: $0,25 \mu \mathrm{g}, 0,5 \mu \mathrm{g}, 1 \mu \mathrm{g}$ and $3 \mu \mathrm{g}$. As, shown in Fig. 1, the dose dependent activity of specific siRNA was observed on P2Y, protein level between $0,25 \mu \mathrm{g}$ and $1 \mu \mathrm{g}$. There is no visible effect of this inhibition on the observed level of $\mathrm{P}_{2} \mathrm{Y}_{12}$ protein level. Presented blots come from two representative experiments, $\beta$-actin as housekeeping protein reference.

causes: the siRNA delivery efficiency and the relatively slow receptor protein turnover. The latter possibility is supported also by our data from TIRF imaging, showing gradual transfer of the $\mathrm{P}_{2} \mathrm{Y}_{1}$ receptors from ventral plasma membrane into the cytoplasm.

The observed physiological effects of inhibition of Phosphorylation of Erk1/2 and Akt kinases after silencing of $\mathrm{P}_{2} \mathrm{Y}_{1}$ receptors follows the Sak and Illes postulate that a general property of neuronal malignant cells appears to be the absence of $\mathrm{P}_{2} \mathrm{Y}_{1}$ receptor and inhibition of PI3-K/Akt signaling (Sak \& Illes, 2005). In the present study the effect is much more pronounced than in the serum deprivation paper, where Akt signaling was strongly affected after long-term experiment (Krzeminski, et al., 2007). Moreover, our previous work clearly shows that $\mathrm{P}_{2} \mathrm{Y}_{12}$ receptors have a positive, modulatory influence (via cAMP-dependent pathways) on the $\mathrm{P}_{2} \mathrm{Y}_{1}$ dependent calcium signaling (Suplat, et al., 2007). However, the mechanism proposed by Hardy et al. (2004) for platelets does not seem to depend strongly on the $\mathrm{P}_{2} \mathrm{Y}_{12}$ receptor protein level itself, even if the activation of this receptor strongly affects the cAMP level in glioma C6 cells via $\mathrm{G}_{\mathrm{i}}$ protein (Van Kolen \& Slegers 2004). Moreover, the $\mathrm{P} 2 \mathrm{Y}_{1}$-evoked calcium signal observed in the present work in glioma C6 cells was much less sensitive to the siRNA dose than the receptor protein level itself. Those discrepancies between the receptor protein level and the signaling efficiency can, however, have much deeper roots.

Several years ago it was discovered that another nucleotide receptor, $\mathrm{P} 2 \mathrm{Y}_{2}$, can interact with integrins, changing the signaling activity after entering into complex with $\alpha_{v} \beta_{5}$ integrins (Bagchi et al., 2005) and changing its $G$ protein $\alpha$ subunit specificity from $G_{\mathrm{q}}$ to $G_{12}$ (Liao et al., 
2007). This change switches the signal from the receptor and instead of inducing the calcium transient the receptor directly activates RhoA-dependent signaling pathway (Suzuki et al., 2003). This quite unique double specificity of GPRS receptors to $G_{q}$ and $G_{12 / 13}$ subunits of heterotrimeric $G$ proteins may lead to the situation in which the level of receptor protein does not exactly correlate with the signal from this receptor. Even if the ability to bind integrins was described only for ATP-induced P2Y receptors, notions of integrin-dependent ADP nucleotide signaling appeared recently (O’Brien et al., 2012) as well as the $\mathrm{P} 2 \mathrm{Y}_{12}$-dependent integrin activity influencing microglia cell spreading under the ADP stimulation (Ohsawa et al., 2010).

Summarizing, this paper shows that nucleotide signaling is an interplay of two proteins more complicated than previously postulated and the cross-talk between receptors may be very indirect and finely modulated by the cell structure and function.

\section{Acknowledgements}

Authors were supported by grant NN303 070434 from the Ministry of Science and Higher Education.

\section{REFERENCES}

Abbracchio MP, Burnstock G (1998) Purinergic signalling: pathophysiological roles. Jpn J Pharmacol 78: 113-145.

Auer RN, Del Maestro RF, Anderson R (1981) A simple and reproducible experimental in vivo glioma model. The Can J Neurol Sci 8: 325-331.

Bagchi S, Liao Z, Gonzalez FA, Chorna NE, Seye CI, Weisman GA, Erb L (2005) The P2Y2 nucleotide receptor interacts with alphav integrins to activate Go and induce cell migration. J Biol Chem 280: 39050-39057.

Baranska J, Chaban V, Czarny M, Sabala P (1995) Changes in $\mathrm{Ca}^{2+}$ concentration in phorbol ester and thapsigargin treated glioma C6 cells. The role of protein kinase $\mathrm{C}$ in regulation of $\mathrm{Ca}^{2+}$ entry. Cell calcium 17: 207-215.

Benda P, Lightbody J, Sato G, Levine L, Sweet W (1968) Differentiated rat glial cell strain in tissue culture. Science (New York, N.Y 161: 370-371.

Braganhol E, Huppes D, Bernardi A, Wink MR, Lenz G, Battastini AM (2009) A comparative study of ectonucleotidase and P2 receptor mRNA profiles in C6 cell line cultures and C6 ex vivo glioma model. Cell Tissue Res 335: 331-340.

Brismar T (1995) Physiology of transformed glial cells. Glia 15: 231243.

Burnstock G (1976) Purinergic receptors. J Theor Biol 62: 491-503.

Burnstock G (2007) Physiology and pathophysiology of purinergic neurotransmission. Physiol Rev 87: 659-797.

Crooke A, Mediero A, Guzman-Aranguez A, Pintor J (2009) Silencing of P2Y2 receptor delays Ap4A-corneal re-epithelialization process. Mol Vis 15: 1169-1178.

Czajkowski R, Banachewicz W, Ilnytska O, Drobot LB, Baranska J (2004) Differential effects of P2Y1 and P2Y12 nucleotide receptors on ERK1/ERK2 and phosphatidylinositol 3-kinase signalling and cell proliferation in serum-deprived and nonstarved glioma C6 cells. Br J Pharmacol 141: 497-507.

De Vuyst E, Decrock E, Cabooter L, Dubyak GR, Naus CC, Evans WH, Leybaert L (2006) Intracellular calcium changes trigger connexin 32 hemichannel opening. EMBO J 25: 34-44.
Deli T, Varga N, Adam A, Kenessey I, Raso E, Puskas LG, Tovari J, Fodor J, Feher M, Szigeti GP, Csernoch L, Timar J (2007) Functional genomics of calcium channels in human melanoma cells. Int J Cancer 121: 55-65.

Edelstein A, Amodaj N, Hoover K, Vale R, Stuurman N (2010) Computer control of microscopes using microManager. Current Protocols in Molecular Biology. Frederick M. Ausubel FM et al. eds. Chapter 14: Unit14 20.

Grynkiewicz G, Poenie M, Tsien RY (1985) A new generation of $\mathrm{Ca}^{2+}$ indicators with greatly improved fluorescence properties. $J$ Biol Chem 260: 3440-3450.

Harden TK, Sesma JI, Fricks IP, Lazarowski ER (2010) Signalling and pharmacological properties of the P2Y receptor. Acta Physiol (Oxford, England) 199: 149-160.

Hardy AR, Jones ML, Mundell SJ, Poole AW (2004) Reciprocal crosstalk between P2Y1 and P2Y12 receptors at the level of calcium signaling in human platelets. Blood 104: 1745-1752.

Jacobs VL, Valdes PA, Hickey WF, De Leo JA (2011) Current review of in vivo GBM rodent models: emphasis on the CNS-1 tumour model. ASN Neuro 3: e00063.

Krzeminski P, Suplat D, Czajkowski R, Pomorski P, Baranska J (2007) Expression and functional characterization of P2Y1 and P2Y12 nucleotide receptors in long-term serum-deprived glioma C6 cells. FEBS J 274: 1970-1982.

Krzeminski P, Pomorski P, Baranska J (2008) The P2Y $\mathrm{Y}_{14}$ receptor activity in glioma C6 cells. Eur J Pharmacol 594: 49-54.

Liao Z, Seye CI, Weisman GA, Erb L (2007) The P2Y2 nucleotide receptor requires interaction with alpha $\mathrm{v}$ integrins to access and activate G12. I Cell Sci 120: 1654-1662.

Martin-Gil A, de Lara MJ, Crooke A, Santano C, Peral A, Pintor J (2012) Silencing of P2Y(2) receptors reduces intraocular pressure in New Zealand rabbits. Br I Pharmacol 165: 1163-1172.

North RA (2002) Molecular physiology of P2X receptors. Physiol Rev 82: 1013-1067.

O’Brien KA, Gartner TK, Hay N, Du X (2012) ADP-stimulated activation of Akt during integrin outside-in signaling promotes platelet spreading by inhibiting glycogen synthase kinase-3beta. Arterioscler Thromb V asc Biol 32: 2232-2240.

Ohsawa K, Irino Y, Sanagi T, Nakamura Y, Suzuki E, Inoue K, Kohsaka S (2010) P2Y12 receptor-mediated integrin-beta1 activation regulates microglial process extension induced by ATP. Glia 58: $790-801$.

Rasmussen H, Jensen P, Lake W, Goodman DB (1976) Calcium ion as second messenger. Clin Endocrinol 5 (Suppl) 11S-27S.

Sak K, Illes P (2005) Neuronal and glial cell lines as model systems for studying P2Y receptor pharmacology. Neurochem Int 47: 401-412.

Schneider CA, Rasband WS, Eliceiri KW (2012) NIH Image to ImageJ: 25 years of image analysis. Nat Methods 9: 671-675.

Suplat-Wypych D, Dygas A, Baranska J (2010) 2', 3'-O-(4benzoylbenzoyl)-ATP-mediated calcium signaling in rat glioma C6 cells: role of the P2Y(2) nucleotide receptor. Purinergic Signal 6: 317-325.

Suplat D, Krzeminski P, Pomorski P, Baranska J (2007) P2Y(1) and $\mathrm{P} 2 \mathrm{Y}(12)$ receptor cross-talk in calcium signalling: Evidence from nonstarved and long-term serum-deprived glioma C6 cells. Purinergic Signal 3: 221-230.

Suzuki N, Nakamura S, Mano H, Kozasa T (2003) Galpha 12 activates Rho GTPase through tyrosine-phosphorylated leukemia-associated RhoGEF. Proc Natl Acad Sci USA 100: 733-738.

Van Kolen K, Slegers H (2004) P2Y12 receptor stimulation inhibits beta-adrenergic receptor-induced differentiationby reversing the cyclic AMP-dependent inhibition of protein kinase B. J Neurochem 89 : 442-453.

Wei W, Ryu JK, Choi HB, McLarnon JG (2008) Expression and function of the $\mathrm{P} 2 \mathrm{X}(7)$ receptor in rat C6 glioma cells. Cancer Lett 260: 79-87.

Wypych D, Baranska J (2013) Cross-talk in nucleotide signaling in glioma C6 cells. Adv Exp Med Biol 986: 31-59. 